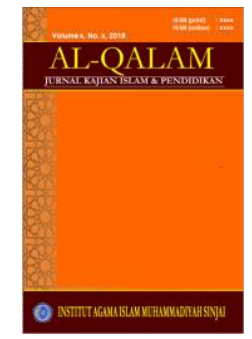

AL-QALAM

Jurnal Kajian Islam \& Pendidikan

Volume 7, No. 1, 2015

ISSN (print) : 1858-4152

ISSN (online) : 2715-5684

Homepage : http://journal.al-qalam.iaims.ac.id

\title{
BELAJAR DAN FAKTOR YANG MEMPENGARUHINYA
}

\author{
Oleh: Sardiyanah ${ }^{*}$
}

$* * *$

\begin{abstract}
Abstrak
Salah satu masalah yang dihadapi dunia pendidikan kita adalah masalah lemahnya minat belajar siswa, sehinggah berdampak pada kualitas pendidikan dan itu semua terjadi bukan karna tanpa sebab, melainkan ada faktor yang mempengaruhinya. Belajar adalah kegiatan manusia yang sangat penting dan harus dilakukan selama hidup, karna melalui belajar dapat melakukan perbaikan dalam berbagai hal yang menyangkut kepentingan hidup, dengan kata lain melalui belajar dapat memperbaiki nasib, menggapai cita-cita yang di dambakan. Belajar itu sendiri adalah suatu usaha atau kegiatan, yang bertujuan mengadakan perubahan di dalam diri seseorang, mencakup perubahan tingkah laku, sikap, kebiasaan, ilmu pengetahuan serta keterampilan dan sebagainya. Orang dapat dikatakan belajar ketika terjadi perubahan dalam dirinya dan bersifat permanen dan bukan bersifat sementara. Perubahan adalah perubahan ke arah yang lebih baik, dari tidak tahu menjadi tahu. Dalam belajar terdapat beberapa faktor yang dapat mempengaruhi siswa dalam belajar, baik internal (dalam) maupun eksternal (luar). Faktor internal berasal dari siswa itu sendiri berupa fisiologis dan psikologis. Sedangkan faktor eksternal adalah berasal dari luar berupa lingkungan keluarga, lingkungan sekolah, dan lingkungan masyarakat. Dalam menerjemahkan perubahan yang terjadi dan faktor yang mempengaruhi dalam belajar, penulis mencoba menjabarkan mengenai halhal terkait dengan belajar itu sendiri dan berbagai faktor yang mempengaruhnya mulai dari jenis belajar sampai pada bagaimana usaha mengatasi kesulitan belajar sehingga dapat meningkatkan prestasi siswa dan kualitas pendidikan. Selain itu, menjabarkan pula apa saja yang menjadi problem dalam belajar siswa.
\end{abstract}

Kata Kunci: Pendidikan, Belajar, Pengaruh, Faktor

\section{PENDAHULUAN}

Pendidikan adalah suatu proses dalam rangka mempengaruhi peserta didik menyesuaikan diri sebaik mungkin dengan lingkunganya, dengan demikian akan

\footnotetext{
* Dose Tetap STAI Muhammadiyah Sinjai
} 


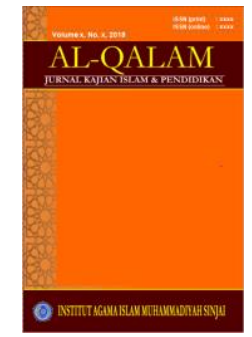

AL-QALAM

Jurnal Kajian Islam \& Pendidikan

Volume 7, No. 1, 2015

ISSN (print) : 1858-4152

ISSN (online) : 2715-5684

Homepage : http://journal.al-qalam.iaims.ac.id

menimbulkan perubahan dalam dirinya yang memungkinkan untuk berpungsi dalam kehidupan masyarakat. Sehinggah permasalahan pendidikan tidak hanya terletak pada siswa dan guru tetapi masyarakat dan pemerintah juga turut andil dalam masalah pendidikan. ${ }^{1}$

Pendidikan yang dimaksud disini adalah proses belajar mengajar secara formal di lembaga pendidikan khususnya sekolah. Adapun pengertian belajar itu sendiri, salah satunya menurut M. Dalyono belajar adalah suatu usaha atau kegiatan, yang bertujuan mengadakan perubahan di dalam diri seseorang, mencakup perubahan tingkah laku, sikap, kebiasaan, ilmu pengetahuan serta keterampilan dan sebagainya. ${ }^{2}$ Belajar adalah kegiatan manusia yang sangat penting dan harus dilakukan selama hidup, karna melalui belajar dapat melakukan perbaikan dalam berbagai hal yang menyangkut kepentingan hidup, dengan kata lain melalui belajar dapat memperbaiki nasib, menggapai cita-cita yang didambakan.

Untuk menghadapi perkembangan ilmu pengetahuan dan teknologi yang semakin canggih dan arus globalisasi yang semakin hebat sehingga banyak persaingan dalam berbagai hal yang menuntut peningkatan Sumber Daya Manusia (SDM) terutama untuk menciptakan sumber daya manusia yang berkualitas dan berprestasi.

Ada banyak faktor yang dapat mempengaruhi siswa dalam belajar. Faktor-faktor itu dari internal dan juga eksternal. Kita bisa mengetahui dan membedakan faktor mana saja yang bisa meningkatkan belajar siswa. Banyak kasus penyebab kegagalan studi di sebabkan karna kurangnya ketidaktahuan apa saja faktor yang mengganggu belajar siswa.

Keberhasilan untuk meningkatkan lulusan dapat dilihat dari hasil belejar siswa yang merupakan hasil dari proses belajar siswa yang dipengaruhi oleh banyak faktor. Salah satu diangtaranya yang paling pokok yaitu minat belajar. Sedangkan minat belajar dipengaruhi oleh faktor interen dan faktor eksteren.

\section{PEMBAHASAN}

\section{A. Pengertian Belajar}

Belajar adalah perubahan yang relatif permanen dalam prilaku atau potensi prilaku sebagai hasil dari pengalaman atau latihan yang diperkuat. Belajar merupakan akibat adanya interaksi angtara stimulus dan respon. Seseorang dianggap telah belajar sesuatu jika ia dapat

\footnotetext{
${ }^{1}$ Tity Setyorini, Strategi Pembelajaran Pendidikan Agama Islam di Sekolah, Teori, Metedologi dan Implementasi, (Yogyakarta: Idea Press, Cet. Pertama, 2012), hlm. 99.

${ }^{2}$ M. Dalyono, Psikologi Pendidikan, (Jakarta: Rineka Cipta, 1997), hlm. 49.
} 


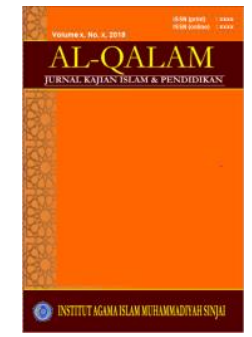

AL-QALAM

Jurnal Kajian Islam \& Pendidikan

Volume 7, No. 1, 2015

ISSN (print) : 1858-4152

ISSN (online) : 2715-5684

Homepage : http://journal.al-qalam.iaims.ac.id

menunjukkan perubahan prilakunya. Menurut teori ini dalam belajar yang pentin adalah input berupa stimulus dan output yang berupa respon. ${ }^{3}$

Stimulus adalah apa aja yang diberikan guru kepada pelajar, sedangkan respon berupa reaksi atau tanggapan pelajar terhadap stimulus yang diberikan oleh guru tersebut. Proses yang terjadi angtara stimulus dan respon tidak penting untuk diperhatikan karna tidak dapat diamati dan tidak dapat di ukur, yang dapat diamati adalah stimulus dan respon, oleh karna itu apa yang diberikan oleh guru (stimulus) dan apa yang diterima oleh pelajar (respon) harus dapat diamati dan diukur.

Belajar adalah modifikasi atau memperteguh kelakuan melalui pengalaman. Dalam artian belajar merupakan suatu proses, sustu kegiatan dan bukan suatu hasil atau tujuan. Belajar bukan hanya mengingat, akan tetapi lebih luas dari itu, yakni mengalami. Hasil belajar bukan suatu penguasaan hasil latihan melainkan pengubahan kelakuan. ${ }^{4}$

Menurut W.S Winkel yang dikutip oleh Suharyanta, belajar adalah sustu aktivitas psikis yang berlangsung dalam interaksi aktif dengan lingkungan, yang menghasilkan perubahan dalam pengetahuan, keterampilan dan nilai sikap. ${ }^{5}$ Dalam pandangan konstruktivisme, ada dua jenis belejar yaitu belajar bermakna dan belajar menghafal. Belajar bermakna adalah suatu proses belajar dimana informasi baru dihubungkan dengan struktur pengertian yang sudah dimiliki seseorang yang sedang belajar. Ini terjadi melalui "belajar konsep" meleui proses asimilasi atau akomodasi. Sementara itu, bila konsep yang cocok dengan fenomena (informasi) baru itu belum ada dalam struktur kognitif seseorang, informasi baru dipelajari lewat "belajar menghafal". Bukan dalam artia pasif, belajar mengahafal disini mengandung arti seseorang mengkonstruksi "konsep" atau struktur pengertian baru.

Menurut Slameto, belajar adalah suatu proses usaha yang dilakukan individu untuk untuk memperoleh suatu perubahan tingkah laku yang baru secara keseluruhan, sebagai hasil pengalaman individu itu sendiri dalam interaksi dengan lingkunganya. ${ }^{6}$ Perubahan yang terjadi dalam diri individu banyak sekali baik sifat maupun jenisnya karna itu sudah tentu tidak setiap perubahan dalam diri individu merupakan perubahan dalam arti belajar. Kalau tangan seorang anak bengkok karna patah tertabrak mobil, perubahan semacam itu tidak

\footnotetext{
${ }^{3}$ Tity Setyorini, Strategi, hlm. 100.

${ }^{4}$ Oemar Hamalik, Proses Belajar Mengajar, (Jakarta: PT Bumi Aksara, Cet. VI, 2007), Hlm. 27.

${ }^{5}$ Suharyanta, Strategi Pembelajaran Pendidikan Agama Islam di Sekolah, Teori, Metedologi dan Implementasi, (Yogyakarta: Idea Press, Cet. Pertama, 2012), hlm. 9.

${ }^{6}$ Slameto, Belajar dan Faktor-Faktor Yang Mempengaruhinya , (Jakarta: Rineka Cipta, 1991), hlm. 2
} 


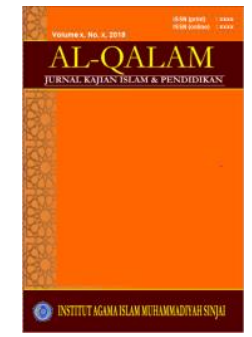

AL-QALAM

Jurnal Kajian Islam \& Pendidikan

Volume 7, No. 1, 2015

ISSN (print) : 1858-4152

ISSN (online) : 2715-5684

Homepage : http://journal.al-qalam.iaims.ac.id

dapat digolongkan kedalam perubahan dalam arti belajar. Demikian pula perubahan tingkah laku seseorang yang berada dalam keadaan mabuk, perubahan yang terjadi dalam aspekaspek kematangan, pertumbuhan dan perkembangan tidak termasuk perubahan dalam pengertian belajar.

Dengan demikian ciri-ciri perubahan dalam tingkah laku dalam pengertian belajar angtara lain:

1. Perubahan yang terjadi secara sadar

Ini berarti bahwa individu yang belajar akan menyadari terjadinya perubahan itu atau sekurang-kuranya individu merasakan telah terjadi adanya suatu perubahan dalam dirinya. Misalnya ia menyadari kalau pengetahuanya bertambah, kecakapanya bertambah, kebiasaanya bertambah.

2. Perubahan dalam belajar bersifat kontinu dan fungsional

Sebagai hasil belajar, perubahan yang terjadi dalam diri individu berlangsun terus menerus dan tidak statis. Satu perubahan yang terjadi akan menyebabkan perubahan perubahan berikutnya dan akan berguna bagi kehidupan ataupun proses belajar berikutnya. Misalnya jika seorang anak belajar menulis, maka ia akan mengalami perubahan dari tidak dapat menulis menjadi dapat menulis. Perubahan ini berlangsung terus hinggah kecakapan menulisnya menjadi lebih baik dan sempurna.

3. Perubahan dalam belajar bersifat positif dan aktif

Dalam perbuatan belajar, perubahan-perubahan itu senantiasa bertambah dan tertuju untuk memperoleh suatu yang lebih baik dari yang sebelumnya. Dengan demikian makin banyak usaha belajar itu dilakukan, makin banyak dan makin baik perubahan yang diperoleh. Perubahan yang bersifat aktif artinya bahwa perubahan itu tidak terjadi dengan sendirinya melainkan karna usaha individu sendiri. Misalnya perubahan tingkah laku karna proses kematangan yang terjadi dengan sendirinya karna dorongan dari dalam, tidak termasuk perubahan dalam pengertian belajar.

4. Perubahan dalam belajar bukan bersifat sementara

Perubahan yang bersifat sementara atau temporer terjadi hanya untuk beberapa saat saja, seperti berkeringat, keluar air mata, bersin, menangis, dan sebagainya, tidak dapat digolongkan sebagai perubahan dalam arti belajar. Perubahan yang terjadi karna proses belajar bersifat menetap atau permanen. Ini berarti tingkah laku yang terjadi setelah belajar akan bersifat menetap atau permanen. 


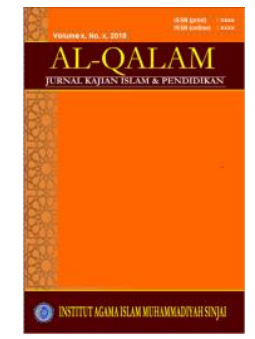

AL-QALAM

Jurnal Kajian Islam \& Pendidikan

Volume 7, No. 1, 2015

ISSN (print) : 1858-4152

ISSN (online) : 2715-5684

Homepage : http://journal.al-qalam.iaims.ac.id

5. Perubahan dalam belajar bertujuan atau terarah

Ini berarti bahwa perubahan tingkah laku itu terjadi karna ada tujuan yang akan dicapai. Perbuatan belajar terarah kepada perbuatan tingkah laku yang benar-benar disadari. Misalnya seorang yang belajar mengetik, sebelumnya sudah menetapkan apa yang mungkin dapat dicapai dengan belajar mengetik atau tingkat kecakapan mana yang akan dicapainya.

William Burton menyimpulkan uraiannya tentang prinsip-prinsip belajar yaitu: ${ }^{7}$

a. Proses belajar ialah pengalaman, berbuat, mereaksi, dan melampaui

b. Proses itu melalui bermacam-macam ragam pengalaman dan mata pelajaran yang terpusat pada suatu tujuan tertentu.

c. Pengalaman belajar secara maksimum bermakna bagi kehidupan murid.

d. Pengalaman belajar bersumber dari kebutuhan dan tujuan murid sendiri yang mendorong motivasi yang kontinu.

e. Proses belajar dan hasil belajar disyarati oleh hereditas dan lingkungan.

f. Proses belajar dan hasil usaha belajar secara materil dipengaruhi oleh perbedaanperbedaan individual dikalangan murid-murid.

g. Proses belajar mengajar berlangsung secara efektif apabila pengalaman-pengalaman dan hasil yang diinginkan disesuaikan dengan kematangan murid.

h. Proses belajar yang terbaik apabila murid mengetahui status kemajuan.

i. Proses belajar merupakan kesatuan fungsional dari berbagai prosedur.

j. Hasil-hasil belajar secara fungsional bertalian satu sama lain, tetapi dapat didisksikan secara terpisah.

k. Proses belajar berlangsung secara efektif dibawah bimbingan yang merangsang dan membimbing tanpa tekanan dan paksaan.

1. Hasil-hasil belajar adalah pola-pola perbuatan, nilai-nilai, pengertian-pengertian, sikapsikap, apresiasi, dan keteampilan.

m. Hasil-hasil belajar diterima oleh murid apabila memberi kepuasan pada kebutuhanya dan berguna serta bermakna baginya.

n. Hasil-hasil belajar dilengkapi dengan jalan serangkaian pengalaman-pengalaman yang dapat dipersamakandan dengan pertimbangan yang baik.

\footnotetext{
${ }^{7}$ Oemar Hamalik, Proses Belajar ...Hlm. 31
} 


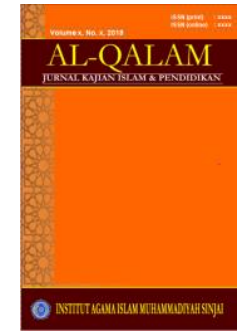

AL-QALAM

Jurnal Kajian Islam \& Pendidlikan

Volume 7, No. 1, 2015

ISSN (print) : 1858-4152

ISSN (online) : 2715-5684

Homepage : http://journal.al-qalam.iaims.ac.id

o. Hasil-hasil belajar yang telah dicapai adalah bersifat kompleks dan dapat berubah-ubah.

\section{B. Jenis Belajar}

Dilihat dari sudut pandang kontruktivisme, ada dua jenis belajar:

a. Belajar Bermakna

Belajar bermakna adalah suatu proses belajar dimana informasi baru dihubungkan dengan struktur pengertian yang sudah dimiliki seseorang yang sedang belajar. Ini terjadi melalui konsep belajar, melalui proses asimilasi dan akomodasi. Sementara itu, bila konsep yang cocok dengan fenomena (informasi) baru dipelajari lewat "belajar menghafal". Belajar menghafal disini mengandung arti seseorang mengonstruksi "konsep" atau struktur pengertian baru. Seperti dikemukakan oleh Arno F. Wittig, setiap proses belajar selalu berlangsung dalam tiga tahapan, yaitu (1) acquiction (pemerolehan informasi), (2) storage (penyimpanan informasi), dan (3) retrieval (mendapatkan kembali informasi; peringatan ulang). ${ }^{8}$

b. Belajar Menghafal

Wina Sanjaya meringkaskan adanya dua pandangan mengenai belajar, (1) belajar dianggap sama dengan menghafal, dan (2) belajar dianggap sebagai proses perubahan tingkah laku sebagai akibat dari pengalaman dan latihan. Pandangan pertama dicirikan oleh belajar menambah sejumlah pengetahuan, belajar berarti mengembangkan kemampuan kognitif, belajar adalah hasil bukan proses, sedangkan pandangan kedua dicirikan dengan belajar adalah aktivitas yang dirancang dan bertujuan, tujuan belajar adalah perubahan tingkah laku secara utuh, belajar bukan hanya sebagai hasil tetapi juga proses dan belajar adalah proses pemecahan masalah.

Secara umum, ada beberapa bentuk kelompok jenis-jenis belajar yaitu angtara lain:

a. Belajar bagian (part learning, fractioned learning)

Umumnya belajar bagian dilakukan oleh individu bila ia dihadapkan pada materi belajar yang bersifat luas atau ekstensif, misalnya belajar sajak ataupun gerakan-gerakan motoris seperti bermain piano.

b. Belajar dengan wawasan (learning by insight)

\footnotetext{
113.

${ }^{8}$ Umi Basiroh, Pembelajaran PAI Strategi dan Metedologi, (Yogyakarta: Idea Pres, 2012, Cet. I), hlm.
} 


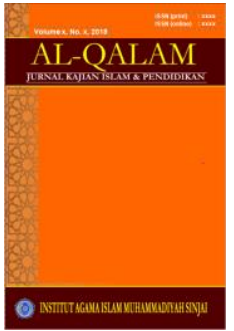

AL-QALAM

Jurnal Kajian Islam \& Pendidlikan

Volume 7, No. 1, 2015

ISSN (print) : 1858-4152

ISSN (online) : 2715-5684

Homepage : http://journal.al-qalam.iaims.ac.id

Konsep ini diperkenalkan oleh W.Kohler, salah seorang tokoh psikologi Gestalt pada permulaan Tahun 1917. Sebagai suatu konsep, wawasan (insight) ini merupakan pokok utama dalam pembicaraan psikologi belajar dan proses berpikir. Dan meskipun W. Kohler sendiri dalam menerangkan wawasan ${ }^{9}$ berorientasi pada data yang bersifat tingkah laku (perkembangan lembut dalam menyelesaikan suatu persoalan dan kemudian secara tiba-tiba terjadi reorganisasi tingkah laku) namun tidak urung wawasan ini merupakan konsep yang secara prinsip ditntang oleh penganut aliran neo-behaviorisme.

c. Belajar diskriminatif (discriminatif learning)

Belajar diskriminatif diartikan sebagai suatu usaha untuk memilih beberapa sifat situasi stimulus dan kemudian menjadikanya sebagai pedoman dalam bertingkah laku.

d. Belajar global/ keseluruhan (global whole learning)

Disini bahan pelajaran dipelajari secara keseluruhan berulang sampai individu menguasainya. Lawan dari belajar bagian. Metode belajar ini sering juga disebut metode Gestalt.

e. Belajar insidental (incidental learning)

Konsep ini bertentangan dengan anggapan bahwa belajar itu selalu berarah tujuan (intensional). Sebab dalam belajar incidental pada individu tidak ada sama sekali kehendak untuk belajar. Atas dasar ini maka untuk kepentingan penelitian, disusun perumusan operasional sebagai berikut: belajar disebut incidental bila tidak ada instruksi atau petunjuk yang diberikan pada individu mengenai materi belajar yang akan diujikan kelak.

f. Belajar instrumental (instrumental learning)

Pada belajar instrumental, reaksi-reaksi individu (murid) yang diperlihatkan diikuti oleh tanda-tandayang mengarah pada apakah individu tersebut akan mendapatkan hadiah, hukuman, berhasil atau gagal. Oleh karna itu cepat atau lambatnya seseorang belajar dapat diatur dengan jalan memberikan penguat (reinforcement) atas dasar tingkat-tingkat kebutuhan.

g. Belajar intensional (intentional learning)

Belajar dengan arah tujuan, merupakan lawan dari belajar incidental.

${ }^{9}$ Menurut Gestalt teori wawasan merupakan proses mereorganisasikan pola-pola tingkah laku yang telah terbentuk menjadi satu tingkah laku yang ada hubunganya dengan penyelesaian suatu persoalan. Sedangkan bagi kaum neo-behaviorisme (C.E. Osgood) menganggap wawasan sebagai salah satu bentuk atau wujud dari asosiasi stimulus respon. Lihat, Umi Basiroh, Pembelajaran, hlm.116. 


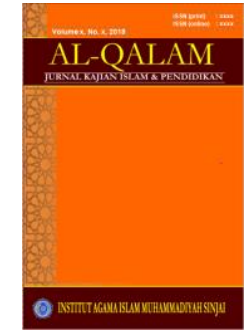

AL-QALAM

Jurnal Kajian Islam \& Pendidlikan

Volume 7, No. 1, 2015

ISSN (print) : 1858-4152

ISSN (online) : 2715-5684

Homepage : http://journal.al-qalam.iaims.ac.id

h. Belajar laten (latent learning)

Dalam belajar laten, perubahan-perubahan tingkah laku yang terlihat tidak terjadi secara segera, dan oleh karna itu disebut laten. Selanjutnya eksprimen yang dilakukan terhadap binatang mengenai belajar laten, menimbulkan pembicaraan yang hangat dikalangan penganut behaviorisme, khususnya mengenai peranan factor penguat (reinforcement) dalam belajar. Sehingga rupa-rupanya penguat dianggap oleh penganut behaviorisme ini bukan factor atau kondisi yang harus ada dalam belajar.

\section{i. Belajar mental (mental learning)}

Perubahan kemungkinan tingkah laku yang terjadi di sini tidak nyata terlihat, melainkan hanya berupa perubahan proses kognitif dari bahan yang dipelajari. Ada tidaknya belajar mental ini sangat jelas terlihat pada tugas-tugas yang sifatnya motoris. Sehinggah atas dasar ini perumusan operasional juga menjadi sangat berbeda.

\section{j. Belajar produktif (productive learning)}

R. Berguis (1964) memberikan arti belajar produktif sebagai belajar dengan transfer yang maksimum.kemungkinan untuk melakukan transfer tingkah laku dari situasi kesituasi lain.

k. Belajar verbal (verbal learning).

Belajar verbal adalah belajar mengenai materi verbal dengan melalui latihan dan ingatan. Dasar dari belajar verbal diperlihatkan dalam eksprimen klasik Ebbinghaus. Sifat eksprimen ini meluas dari belajar asosiatif mengenai hubungan dua kata yang tidak bermakna sampai pada belajar dengan wawasan mengenai penyelesaian persoalan kompleks yang harus diungkapkan secara verbal. ${ }^{10}$

\section{Tiga Modus Anak Belajar}

a. Experience (melalaui pengalaman, keterlibatan aktif (active involment) misalnya: melakukan praktek, mewancarai, keikutsertaan dalam permainan drama,memanipulasi obyek).

b. Obsevation (melalui pengamatan, misalnya: membaca buku gambar tanpa tulisan, memperhatikan peragaan).

c. Language (melalui bahasa, misalnya: berdebat, diskusi, membaca, menyimak cerita yang dibaca keras).

\footnotetext{
${ }^{10}$ Slameto, Belajar. Hlm. 5-11.
} 


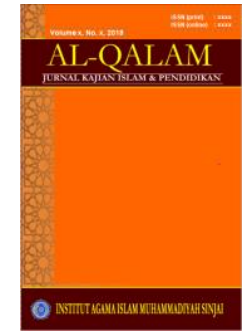

AL-QALAM

Jurnal Kajian Islam \& Pendidikan

Volume 7, No. 1, 2015

ISSN (print) : 1858-4152

ISSN (online) : 2715-5684

Homepage : http://journal.al-qalam.iaims.ac.id

Untuk konteks belajar bahasa, ${ }^{11}$ Tompkins mengusulkan aktivitas yang perlu diupayakan guru bagi siswanya immersion ("mencelupkan" anak dalam kegiatan menyimak, berbicara, membaca dan menulis), employyment (memberi kesempatan anakterlibat dalam kegiatan bahasa yang bermakna, funsional, dan asli), responbility (anak akan menjadi lebih mandiri ketika ia yang dilibatkan ikut menentukan kegitan belajar demonstration anak belajar bahasa melalui demostrasi/ pemeragaan yang ditunjukkan guru), approximation anak akan belajar lebih percaya diri ketika guru tidak menuntut 'ketepatan' melainkan 'peningkatan' melalui kesungguhan mencoba. Espectation (anak akan semangat untuk berhasil ketiga guru mengharapkan mereka menjadi berhasi). ${ }^{12}$

\section{Aktivitas Dalam Belajar}

Setiap situasi dimanapun dan kapan pun memberi kesempatan belajar kepada seseorang. Situasi ini ikut menentukan cara belajar yang dipilih. Berikut ini dikemukakan beberapa contoh aktivitas belajar dalam beberapa situasi:

\section{Mendengarkan}

Contohnya aktivitas ini adalah mendengarkan dosen/ teman presentasi suatu masalah tertentu.

2. Memandang

Dikatakan memandan dalam arti belajar apabila dalam diri kita terdapat kebutuhan, motivasi serta cara tertentu untuk mencapai suatu tujuan.

3. Meraba, membau dan mencicipi/ mencecap

Meraba, membau dan mencecap termasuk aktivitas sensoris seperti hanya mendengarkan dan memandang.

4. Menulis atau mencatat

Dikatakan aktivitas menulis dan mencatat sebagai kegiatan belajar apabila kegiatan bertujuan untuk meraih sesuatu yang berguna.

5. Membaca

\footnotetext{
${ }^{11}$ Dalam konteks belajar bahasa aktivitas yang perlu diupayakan guru bagi siswanya terjadi secara sadar. Ini berarti bahwa individu yang belajar akan menyadari terjadinya perubahan itu atau sekurangkurangnyaindividu merasakan telah terjadi adanya suatu perubahan dalam dirinya. Lihat, Umi Basiroh, Pembelajaran PAI Strategi dan Metodeloginya,(Yogyakarta: Idea Prees, 2012), hlm.114.

${ }^{12}$ Ibid, hlm. 114.
} 


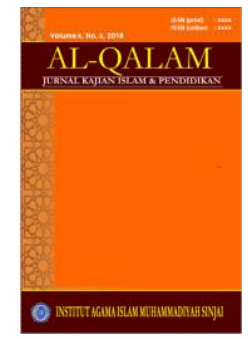

AL-QALAM

Jurnal Kajian Islam \& Pendidikan

Volume 7, No. 1, 2015

ISSN (print) : 1858-4152

ISSN (online) : 2715-5684

Homepage : http://journal.al-qalam.iaims.ac.id

Kegiatan membaca dapat menambah wawasan, cara berfikir yang bertujuan untuk meningkatkan kemampuan intelektualnya yang dapat diaplikasikan dalam kehidupan seharihari disebut aktivitas belajar.

6. Membuat ikhtisar atau ringkasan, menggaris bawahi

Pola ini bermaksud untuk membantu proses belajar dengan membat ikthisar atau meringkas dan menggaris bawahi hal-hal yang penting.

7. Mengamati table-tabel, diagram-diagram dan bagan-bagan.

Materi non verbal seperti ini sangat beruna dalam mempelajari materi yang relevan. Gambargambar, peta-peta dan lain-lain dapat menjadi bahan ilustrasi yang membantu pemahaman tentan suatu hal.

8. Menyusun paper atau kertas kerja.

Termasuk aktivitas belajar, apabila selama proses berusaha untuk membuat sendiri tidak copy paste atau menyontek hasil karya orang lain.

9. Mengingat

Mengingat yang didasari atas kebutuhan serta kesadaran untuk mencapai tujuan belajar lebih lanjut adalah termasuk aktivitas belajar, apalagi jika mengingat berhubungan dengan aktivitas-aktivitas belajar.

10. Berfikir

Dengan berfikir, orang memperoleh penemuan baru setidak-tidaknya orang menjadi tahu tentang hubungan angtar sesuatu.

11. Latihan atau praktek

Orang yang melakukan aktivitas latihan dan praktek tentunya terdorong untuk menguasai hal tertentu yang bermanfaat bagi dirinya sendiri dan berimbas pada orang lain. ${ }^{13}$ Aktivitasaktivitas belajar diatas, digunakan sesuai dengan kebutuhan dan disesuaikan dengan situasi dan kondisi.

\section{E. Faktor Yang Mempengaruhi Belajar}

Faktor yang mempengaruhi prestasi belajar siswa adalah yang pertama cara berfikir. Setiap orang melakukan segala hal dalam hidupnya berdasarkan semua yang ada dalam pemikiranya. Misalnya ada seorang yang tidak suka makan terong. Lalu suatu saat dia diberitahu oleh orang lain bahwa kandungan zat yang ada dalam terong dapat membantu

${ }^{13}$ Wasty Soemanto, Psikologi Pendidikan, (Jakarta: Reineka Cipta, 1990), hlm. 102-109. 


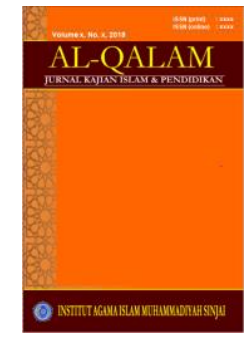

AL-QALAM

Jurnal Kajian Islam \& Pendidikan

Volume 7, No. 1, 2015

ISSN (print) : 1858-4152

ISSN (online) : 2715-5684

Homepage : http://journal.al-qalam.iaims.ac.id

sistem pencernaan tubuh manusia salah satunya terong akan mempermudah buang air besar.

Orang rersebut pada saat itu sedang mengalami gangguan sulit buang air besar maka mencobala dia makan terong. Dan akhirnya ia mempunyai kebiasaan untuk makan terong saat ia sulit buang air besar.

Inilah yang menunjukkan betapa sangat besar pemikiran yang ada dalam otak seseorang dapat mengubah prilaku dan sikap yang dimiliki seseorang. Hal inilah yang perlu diterapkan dalam pendidikan anak untuk meningkatkan prestasi belajar mereka. Jika mungkin selama ini kita sebagai orang tua atau guru hanya menyuruh dan menyuruh untuk anak atau siswa didik kita selalu belajar dan belajar tanpa memberikan penjelasan atau atau alasan lebih kenapa harus belajar.

Proses belajar merupakan hal yang kompleks. Siswalah yang menentukan terjadi atau tidak belajar. Terjadinya suatu proses belajar timbul suatu aktivitas pengalaman belajar. Faktor-faktor yang mempengaruhi belajar ada dua faktor, pertama faktor internal yakni, keadaan atau kondisi jasmani dan rohani siswa dan yang kedua faktor eksternal, yakni kondisi lingkungan/ diluar diri siswa.

1. Faktor Internal (keadaan siswa)

Faktor internal terdiri dari dua faktor, yakni:

a. Faktor fisiologis, yaitu meliputi segala hal yang berhubungan dengan keadaan fisik/ jasmani individu seseorang, dan pada umumnya sangat berpengaruh terhadap kemampuan belajar seseorang. Faktor tersebut meliputi kondisi fisik yang normal dan kondisi kesehatan fisik.

1) Faktor kesehatan

Sehat berarti dalam keadaan baik segenap badan beserta bagiannya/ bebas dari penyakit. Kesehatan adalah keadaan atau hal sehat. Kesehatan seseorang berpengaruh terhadap belajarnya karna proses belajar seseorang akan terganggu jika kesehatan seseorang terganggu, selain itu juga akan cepat lelah, kurang bersemangat, mudah pusing, ngantuk jika badanya lemah, kurang darah ataupun ada gangguan-gangguan/ kelainan-kelainan alat inderanya serta tubuhnya.

Agar seseorang dapat belajar dengan baik haruslah mengusahakan kesehatan badanya tetap terjamin dengan cara selalu mengindahkan ketentuan-ketentuan tentangbekerja, belajar, istirahat, tidur, makan, olahraga, rekreasi dan ibadah. 


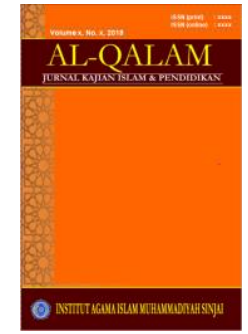

AL-QALAM

Jurnal Kajian Islam \& Pendidlikan

Volume 7, No. 1, 2015

ISSN (print) : 1858-4152

ISSN (online) : 2715-5684

Homepage : http://journal.al-qalam.iaims.ac.id

2) Cacat tubuh

Cacat tubuh adalah sesuatu yang menyebabkan kurang baik atau kurang sempurna mengenai tubuh/ badan. Keadaan cacat tubuh juga mempengaruhi belajar. Siswa yang cacat belajarnya juga terganggu, jika hal ini terjadi maka hendaknya ia belajar pada lembaga pendidikan khusus atau diusaakan alat bantu agar dapat menghindari atau mengurangi pengaruh kecacatan itu.

3) Faktor psikologis

Belajar pada hakekatnya adalah proses psikologis. Oleh karena itu, semua keadaan atau fungsi psikologis tentu saja mempengaruhi belajar seseorang. Faktor tersebut adalah:

a. Minat dan usaha

Menurut Slameto bahwa minat adalah suatu rasa lebih suka dan rasa keterikatan pada suatu hal atau aktivitas, tanpa ada yang menyuruh. Minat pada dasarnya adalah penerimaan akan suatu hubungan angtara diri sendiri dengan sesuatu diluar diri. Semakin kuat atau dekat hubungan tersebut, semakin besar minat. ${ }^{14}$

b. Intelegensi (kecerdasan)

Menurut Wechler dalam Dimyati dan Mudjino, bahwa intelegensi adalahsuatu kecakapan global atau rangkuman kecakapan untuk dapat bertindak secara terarah, berpikir secara baik, dan bergaul dengan lingkungan secara efisien. Kecakapan tersebut menjadi aktual bila siswa memecahkan masalah dalam belajar atau kehidupan sehari-hari. ${ }^{15}$

c. Bakat

Disamping intelegensi, bakat merupakan faktor yang besar pengaruhnya terhadap proses dan hasil belajar seseorang dalam suatu bidang tertentu. Bakat adalah "salah satu kemampuan manusia untuk melakukan suatu kegiatan dan sudah ada sejak manusia itu ada". ${ }^{16}$

d. Motivasi

Motivasi adalah " daya penggerak atau pendorong untuk melakukan sesuatu pekerjaan, yang bisa berasal dari dalam diri dan juga dari luar". ${ }^{17}$ Motivasi yang datang dari dalam diri (intrinsic) yaitu dorongan yang datang dari sanubari, umumnya karna kesadaran akan pentinya sesuatu atau dapat juga karna dorongan bakat apabila ada kesesuaian dengan bidang

\footnotetext{
${ }^{14}$ ibid, hlm. 182 .

${ }^{15}$ Dimyati dan Mudjiono, Belajar dan Pembelajaran, (Jakarta: Rinaka Cipta, 1997), hlm. 57.

${ }^{16}$ Sardiman, Interaksi dan Motivasi Belajar Mengajar, (Jakarta: PT. Raja Grafindo, 2005), hlm. 46.

${ }^{17}$ M. Dalyono, Psikologi, hlm. 57.
} 


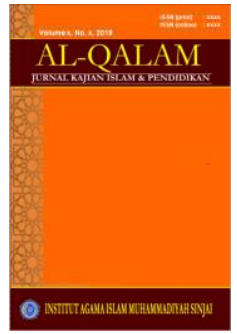

AL-QALAM

Jurnal Kajian Islam \& Pendidlikan

Volume 7, No. 1, 2015

ISSN (print) : 1858-4152

ISSN (online) : 2715-5684

Homepage : http://journal.al-qalam.iaims.ac.id

yang dipelajari. Motivasi yang berasal dari luar (ekstrinsik) yaitu dorongan yang datang dari luar (lingkungan), misalnya dari orang tua, guru teman-teman dan anggota masyarakat. Seseorang yang belajar dengan motivasi kuat, akan melaksanakan semua kegiatan belajarnya dengan sungguh-sungguh, penuh gairah atau semangat. Sebaliknya, belajar dengan motivasi yang lemah, akan malas bahkan tidak mau mengerjakan tugas-tugas yang berhubungan dengan pelajaran. Jadi kuat lemahnya motivasi seseorang turut mempengaruhi keberhasilanya.

Motivasi adalah pemberian semangat untuk terus berusaha dan berusaha agar mendapatkan apa yang ingin dicapai. Seorang anak perlu memiliki motivasi yang tinggi terhadap proses belajar yang ia jalani dan ini muncul dari orang tua atau pihak pendidik. Seorang pendidik idealnya adalah sosok yang sabar dan memiliki motivasi yang tinggi dalam memajukan prestasi belajar peserta didiknya. Motivasi yang tinggi yang dimiliki oleh orang tua dan para pendidik akan menular secara tidak langsung kepada para peserta didiknya. ${ }^{18}$

e. Konsentrasi belajar

Konsentrasi adalah merupakan suatu kemampuan untuk memfokuskan pikiran, perasaan, kemauan, dan segenap panca indra kesatu obyek didalam suatu aktivitas tertentu, dengan disertai usaha untuk tidak memedulikan obyek-obyek lain yang tidak ada hubunganya dengan aktivitas itu. ${ }^{19}$

Pemusatan perhatian (fokus) tertuju pada obyek/ isi bahan belajar maupun proses memperolehnya, dan tidak terpengaruh dengan sekelilinya. Konsentrasi sangat mempengaruhi proses belajar seseorang, apabila konsentrasi menurun tentu mengganggu belajarnya. Hal ini sejalan dengan pendapat Roijakker dalam Dimyati dan Mudjino, mengatakan bahwa "kekuatan perhatian selama 30 menit telahmenurun". Ia menyarankan agar guru memberikan istirahat selingan selama beberapa menit. ${ }^{20}$

\section{f. Kematangan dan kesiapan}

Kematangan merupakan suatu "tingkatan atau fase dalam pertumbuhan seseorang, dimana seluruh organ-organ biologisnya sudah siap untuk melakukan kecakaan baru". ${ }^{21}$ Misalnya

\footnotetext{
${ }^{18}$ http://www.anneahira.com/faktor-faktor-yang-mempengaruhi-prestasi-belajar-siswa.htm, Diunggah pada Tanggal 11 Maret 2013.

${ }^{19}$ Thursan Hakim, Belajar secara Evektif, (Jakarta: Puspa Swara, 2000), hlm. 16.

${ }^{20}$ Dimyati dan Mudjiono, Belajar..hlm. 293.

${ }^{21}$ Tohirin, Psikologi Pembelajaran Pendidikan Agama Islam, (Jakarta: Edisi Revisi, PT. Raja Grafindo Persada, 2006), hlm. 135.
} 


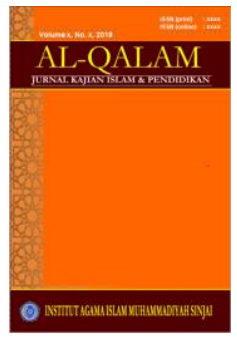

AL-QALAM

Jurnal Kajian Islam \& Pendidlikan

Volume 7, No. 1, 2015

ISSN (print) : 1858-4152

ISSN (online) : 2715-5684

Homepage : http://journal.al-qalam.iaims.ac.id

siap anggota tubuhnya untuk belajar. Dalam konteks proses pembelajaran, kesiapan untuk belajar sangat menentukan aktivitas belajar siswa. Siswa yang belum siap belajar, cenderung akan berprilaku tidak kondusif, sehinggahpada giliranya aan mengganggu proses belajar secara keseluruhan. Seperti siswa yang gelisah, ribut (tidak tenang) sebelum proses belajar dimulai. Jadi kesiapan amat perlu diperhatikan dalam proses belajar mengajar.

g. Kelelahan

Kelelahan pada seseorang walaupun sulit untuk dipisahkan tetapi dapat dibedakan menjadi dua macam, yaitu kelelahan jasmani dan kelelahan rohani. Kelelahan jasmani terlihat dengan lemah lunglainya tubuh dan timbul kecenderungan untuk membaringkan tubuh karna terjadi kekacauan substansi sisa pembakaran didalam tubuh, sehinggah darah tidak/ kurang lancar pada bagian-bagian tertentu. Sedangkan kelelahan rohani dapat dilihat dengan adanya kelesuhan atau kebosanan, sehinggah minat dan dorongan untuk menghasilkan sesuatu hilang, kelelahan ini sangat terasa pada bagian kepala dengan pusing-pusing sehinggah sulit untuk konsetrasi seolah-olah otak kehabisan daya untuk bekerja.

Kelelahan baik secara jasmani maupun rohani dapat dihilangkan dengan cara-cara sebagai berikut:

1) Tidur

2) Istirahat

3) Mengusahan variasi dalam belajar, juga dalam bekerja

4) Menggunkan obat-obatan yang bersifat melancarkan peredaran darah, mialnya obat gosok.

5) Reaksi dan ibadah yang teratur

6) Olahraga secara teratur

7) Mengimbangi makan dengan makanan yang memenuhi syarat-syarat kesehatan

8) Jika kelelahan sangat serius cepat-cepat menghubungi seoran ahli, misalnya dokter, psikiater dan lain-lain.

h. Kejenuhan dalam belajar

Menurut Reber yang dikutip oleh Tohirin bahwa kejenuhan belajar adalah rentang waktu tetentu yang digunakan untuk belajar, tetapi tidak mendatangkan hasil. ${ }^{22}$ Seseorang siswa yang mengalami kejenuhan belajar, sistem akalnya tidak akan bekerja sebagaiman yang

${ }^{22}$ Tohirin, Psikologi, hlm. 141. 


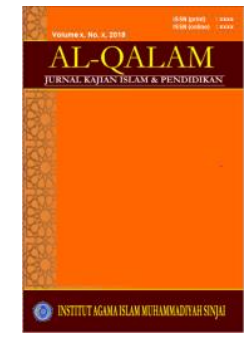

AL-QALAM

Jurnal Kajian Islam \& Pendidikan

Volume 7, No. 1, 2015

ISSN (print) : 1858-4152

ISSN (online) : 2715-5684

Homepage : http://journal.al-qalam.iaims.ac.id

diharapkan dalam memproses item-item informasi atau pengalaman baru, sehinggah kemajuan belajarnya seakan-akan mandeg tidak mendatangkan hasil

\section{Faktor Eksternal Siswa}

\section{a. Faktor Lingkungan Keluarga}

Keluarga adalah "Ayah, ibu, dan anak-anak serta famili yang menjadi penghuni rumah". ${ }^{23}$ Faktor lingkungan rumah atau keluarga ini merupakan lingkungan pertama dan utama dalam menentukan perkembangan pendidikan seseorang, dan tentu saja merupakan faktor pertama dan utama pula dalam menentukan keberhasilan belajar seseorang.

Orang tua adalah penanggun jawab keluarga. Dalam pendidikan keluarga menjadi suatu kebutuhan yang mendasar, sebab keluarga adalah awal dimana anak mengenal orang lain dan dirinya sendiri, serta pertama-tama mendapatkan pendidikan, yaitu pendidikan yang diberikan oleh kedua orang tuanya dan merupakan kewajiban yang bersifat kodrati dan bersifat agamis. Hal ini diterangkan dalam firman Allah surah at-Tahriim ayat $6^{24}$ :

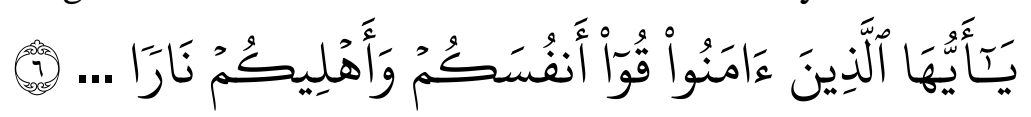

"Hai orang-orang yang beriman, peliharalah dirimu dan keluargamu dari api neraka".

Ayat tersebut, jelas peran orang tua dilingkungan keluarga sangat memegang kunci. Keluarga merupakan pusat pendidikan yang utama dan pertama. Yang termasuk faktor ini angtara lain: ${ }^{25}$

1) Perhatian orang tua; Dalam lingkungan keluarga setiap individu atau siswa memerlukan perhatian orang tua dalam mencapai prestasi belajarnya. Karna perhatian orang tua ini akan menentukan seseorang siswa dapat mencapai prestasi belajar yang tinggi.. perhatian orang tua diwujudkan dalam hal kasih sayang, memberi nasehat-nasehat dan sebagainya.

2) Keadaan ekonomi orang tua; Keadaan ekonomi keluarga juga mempengaruhi prestasi belajar siswa, terkadang siswa merasa kurang percaya diri dengan keadaan ekonomi keluarganya. Akan tetapi ada juga siswa yang keadaan ekonominya baik, tetapi prestasi belajarnya rendah atau sebaliknya siswa yang keadaan ekonominya rendah malah mendapat prestasi belajar yang tinggi.

\footnotetext{
${ }^{23}$ M. Dalyono, Psikologi, hlm. 59

${ }^{24}$ Departemen Agama RI, Al-Qur'an dan Terjemahanya, CV Penerbit J-ART, Bandun, 2005, hlm 560.

${ }^{25}$ Tity Setyorini, Strategi Pembelajaran, hlm. 106.
} 


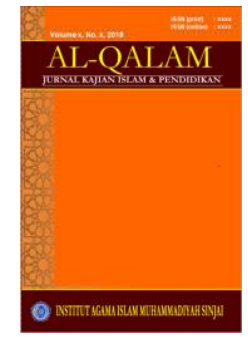

AL-QALAM

Jurnal Kajian Islam \& Pendidlikan

Volume 7, No. 1, 2015

ISSN (print) : 1858-4152

ISSN (online) : 2715-5684

Homepage : http://journal.al-qalam.iaims.ac.id

3) Hubungan angtara anggota keluarga; Dalam keluarga harus terjadi hubungan yang harmonis antar personil yang ada. Dengan adanya hubungan yang harmonis antar keluarga akan mendapat kedamaian, ketenangan dan ketentraman. Hal ini dapat menciptakan kondisi belajar yang baik, sehinggah prestasi belajar siswa dapat tercapai dengan baik pula.

b. Faktor Lingkungan Sekolah

Sekolah adalah lembaga formal terjadinya proses belajar mengajar. Selain pendidikan dalam keluarga, pendidikan disekolah diperoleh secara teratur, sistematis, bertingkat mulai TK sampai perguruan tinggi.

Beberapa hal yang menunjang keberhasilan belajar seseorang di sekolah diangtaranya adalah:

1) Kurikulum yang baik; Kurikulum yang baik adalah yang sesuai dengan kemampuan siswa, sedangkan kurikulum yang kurang baik adalah kurikulm yang terlalu padat, didtas kemampuan siswa. Kurikulum diartikan sebagai sejumlah kegiatan yang diberikan kepada siswa. Kegiata itu sebagian besar adalah menyajikan bahan pelajaran agar siswa menerima, menguasai dan mengambangkan pelajaran itu. Perlu diingat bahwa sistem intruksionsl sekarang menghendaki proses belajar mengajar yang mementingkan kebutuhan siswa, guru perlu pendalami siswa dengan baik, harus mempunyai perencanaan yang mendetail, agar dapat melayani siswa secara individual.

2) Sarana prasarana; Lengkapnya sarana dan prasarana pembelajaran merupakan kondisi pembelajaran yang baik, karna adanya gedung sekolah dengan lengkap fasilitas belajar, seperti buku pegangan anak, ruang ibadah, labolatorium dan lain-lain. Anak didik dapat belajar dengan baik apabila suatu sekolah memenuhi segala kebutuhan belajar anak didik.

3) Tata tertib dan disiplin; Menurut Thursan hakim bahwa salah satu yang paling mutlak harus ada di sekolah untuk menunjang keberhasilan belajar adalah adanya tata tertib dan disiplin yang ditegakkan secara konsekuen dan konsisten. ${ }^{26}$ Disiplin tersebut harus ditegakkan secara menyeluruh dari pimpinan sekolah yang bersangkutan, para guru, siswa sampai para karyawan sekolah lainya. Dengan cara inilah dapat mempengaruhi prestasi belajar para siswa.

\footnotetext{
${ }^{26}$ Thursan Hakim, Belajar...,hlm. 18.
} 


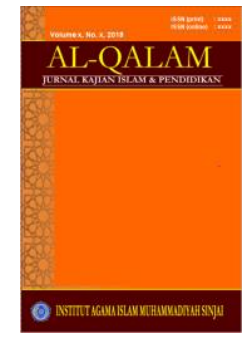

AL-QALAM

Jurnal Kajian Islam \& Pendidikan

Volume 7, No. 1, 2015

ISSN (print) : 1858-4152

ISSN (online) : 2715-5684

Homepage : http://journal.al-qalam.iaims.ac.id

4) Guru; Guru adalah salah satu komponen manusiawi dalam proses belajar mengajar, yang ikut berperan dalam usaha pembentukan sumber daya manusia yang potensial dibidang pembangunan. Guru yang baik adalah guru yang profesional, mengajar sesuai dengan keahlianya. Guru profesional disini dalam interaksi belajar mengajar diangtaranya adalah sebagai berikut:

a) Relasi guru dengan siswa; Proses interaksi siswa dengan guru, dipengaruhi hubungan yang ada. Apabila guru dapat berinteraksi dengan siswa yang baik, akrab, siswa akan menyukai gurunya, juga akan menyukai mata pelajaran yang diberikan oleh guru, sehinggah siswa mempelajarinya dengan sebaik-baiknya.

b) Relasi siswa dengan siswa

Relasi siswa dengan siswa yaitu hubungan yang akan mempengaruhi proses belajar, apabila siswa mempunyai sifat-sifat atau tingkah laku yang kurang menyenangkan teman lain, rendah diri, mengalami tekanan batin akan diasingkan dari kelompok. Ia menjadi malas sekolah karna mengalami perlakuan kurang bagus dari temanya. Jadi perlu hubungan baik angtar siswa, agar dapat memberikan pengaruh yang positif terhadap belajar mengajar siswa. ${ }^{27}$

c. Faktor Lingkungan Masyarakat

1) Kegiatan siswa dalam masyarakat. Kegiatan siswa dalam masyarakat dapat menguntungkan terhadap perkembangan pribadinya. Tetepi kalau kegiatan siswa terlalu banyak maka akan tergaggu belajarnya, karna ia tidak bisa mengatur waktu.

2) Media massa. Yang dimaksud dalam media massa adalah bioskop, radio, TV, surat kabar, buku-buku, komik dan lain-lain.media massa yang baik akan memberi pengaruh yang baik terhadap siswa dan juga terhadap belajarnya. Sebaiknya media massa yang jelek juga berpengaruh jelek terhadap siswa.

3) Teman bergaul. Pengaruh dari teman bergaul siswa lebih cepat masuk dalam jiwanya daripada yang kita duga. Teman yang baik membawa kebaikan, seperti membawa belajar bersama, dan teman pergaulan yang kuran baik adalah yang suka begadang, pecandu rokok, pemabuk maka berpengaruh sifat buruk juga.

4) Bentuk kehidupan masyarakat. Apabila kehidupan masyarakat yang terdri dari orangorang berpendidikan, terutama anak-anaknya rata-rata bersekolah tinggi dan moralnya

${ }^{27}$ Slameto, Belajar, hlm. 68-69. 


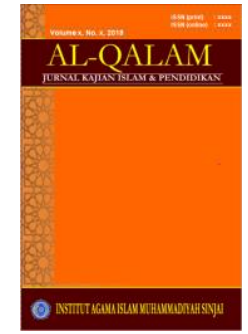

AL-QALAM

Jurnal Kajian Islam \& Pendidikan

Volume 7, No. 1, 2015

ISSN (print) : 1858-4152

ISSN (online) : 2715-5684

Homepage : http://journal.al-qalam.iaims.ac.id

baik. Masyarakat yang terdiri dari orang-oarang tidak terpelajar, pejudi, suka mencuri dan mempunyai kebiasaan yang tidak baik, akan berpengaruh jelek kepada anak yang berada di lingkungan itu. ${ }^{28}$

5) Lingkungan sekitar. Keadaan lingkungan, bangunan rumah, suasana sekitar, keadaan lalu lintas dan sebagainya. Misalnya bangunan rumah penduduk yang sangat sempit, lalu lintas yang membisingkan, suasana hiruk-pikuk orang disekitar, suara pabrik, polusi udara, iklim yang terlalu panas, semuanya akan mempengaruhi gairah dan minat belajar. Sebaliknya tempat yang sepi dengan iklim yang sejuk, ini akan menunjang proses belajar. Keadaan alam yang tenang dengan udara yang sejuk ikut mempengaruhi kesegaran jiwa murid sehinggah memungkinkan hasil belajarnya akan lebih tinggi dari pada lingkungan yang gaduh dengan udarah yang panas dan kotor.

\section{F. Pentinya peran guru bagi belajar siswa}

Meski iptek sudah sedemikian maju, peran guru tidak bias sepenuhnya "digantikan" oleh kecanggihan teknologi karna kegiatan pendidikan tetap membutuhkan "personifikasi" guru (seperti keteladanan dan kehangatan guru dalam interaksi edukatif dengan peserrta didik).

Perbedaan "guru" dengan "pemikir/ pakar"; guru mampu membuat sesuatu yang "sulit" menjadi "mudah" (mudah dipahami, dicerna, dikuasai peserta didik), sedangkan pemikir/ pakar mampu membuat sesuatu yang "mudah" menjadi "sulit" (karna tidak sembarang orang bias menangkap apa yang ia sampaikan). ${ }^{29}$ Manusia pada dasarnya adalah "mahluk pembelajar". Bahkan riset meunjukkan bahwa anak pada awal perkembanganya memiliki rasa ingin tahu dan kemauan belajar setara dengan rasa ingin tahu/ semangat belajar ilmuawan yang sedang aktif melakukan penelitian di laboratorium. Apabila kemudian ia mengalami learning shutdown (padamnya semangat belajar), maka karna tiadanya dukungan suportif dari significant others, seperti guru orang tua dan keluarga.

\section{G.Hasil Belajar}

Setelah seseorang melakukan suatu aktivitas belajar, dia akan memperoleh suatu hasil belajar. Hasil belajar adalah perubahan tingkah laku yang relative permanen. Hasil belajar akan nampak pada perubahan aspek pengetahuan, pengertian, kebiasaan, keterampilan,

\footnotetext{
${ }^{28}$ M. Dalyono, Psikologi, hlm. 60.

${ }^{29}$ Umi Basiroh, Pembelajaran, hlm. 123-124.
} 


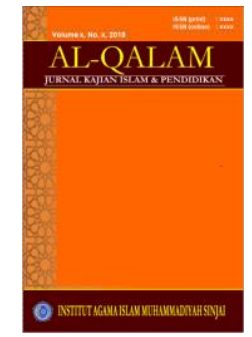

AL-QALAM

Jurnal Kajian Islam \& Pendidlikan

Volume 7, No. 1, 2015

ISSN (print) : 1858-4152

ISSN (online) : 2715-5684

Homepage : http://journal.al-qalam.iaims.ac.id

apresiasi, emosional, hubungan social, jasmani, budi pekerti dan sikap. Sedang dari sumber lain disebutkan bahwa hasil belajar itu meliputi: (1) keterampilan dan kebiasaan, (2) pengetahuan dan pengertian, (3) sikap dan cita-cita. Menurut Gagne, hasil belajar terdiri dari lima kemampuan yang dapat dijabarkan sebagai berikut: (1) keterampilan intelektual, (2) penggunaan strategi kognitif, (3) sikap, (4) invormasi verbal dan (5) keterampilan motorik. Penulis berpendapat dari beberapa tentang hasil belajar diatas, dapat disimpulkan bahwa secara garis besar, hasil belajar itu meliputi 3 ranah yaitu kognitif, afektif, dan psikomotorik.

\section{H.Usaha Mengatasi Kesulitan Belajar}

Mengalami kesulitan belajar, tidak dapat dipisahkan dari faktor-faktor kesulitan belajar sebagaimana diuraikan diatas. Karna itu, mencari sumber penyebab utama dan sumbersumber penyebab peserta lainya, adalah menjadi mutlak adanya dalam rangka mengatasi kesulitan belajar. Secara garis besar langkah-langkah yang ditempih dalam rangkah mengatasi kesulitan belaja, dapat dilakukan melalui lima tahap:

1. Pengumpulan data

Untuk menemukan sumber penyebab kesulitan belajar, diperlukan banyak informasi. Untuk memperoleh informasi tersebut, maka perlu diadakan suatu pengamatan langsung yang disebut dengan pengumpulan data. Menurut Sam Isbani dan R.Isbani dalam pengumpulan data dapat digunakan berbagai metode, diangtaranya adalah: observasi, kunjungan rumah, case study, case histories, daftar pribadi, meneliti pekerjaan anak, tugas kelompok, melaksanakan tes (baik tes IQ maupun tes prestasi/ achievement test). Dalam pelaksanaanya, metode-metode tersebut tidak harus semuanya digunakan secara bersama-sama akan tetapi tergantung pada masalahnya, kompleks atau tidak.

\section{Pengelolaan Data}

Data yang telah terkumpul dari kegiatan tahap pertama tersebut, tidak ada artinya jika tidak diadakan pengelolaan secara cermat. Semua data harus diolah dan dikaji untuk mengetahui secara pasti sebab-sebab kesulitan belajar yang dialami oleh anak. Dalam pengelolaan data, langkah yang dapat ditempuh angtara lain adalah:
a) Identifikasi kasus
b) Membandingkan angtar kasus
c) Membandingkan dengan tes
d) Menarik kesimpulan 


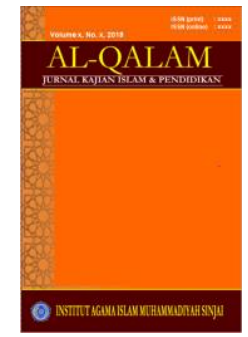

AL-QALAM

Jurnal Kajian Islam \& Pendidlikan

Volume 7, No. 1, 2015

ISSN (print) : 1858-4152

ISSN (online) : 2715-5684

Homepage : http://journal.al-qalam.iaims.ac.id

e) Diagnosis

Diagnosis adalah keputusan (penentuan) mengenai hasil dari pengelolaan data. Diagosis ini dapat berupa hal-hal sebagai berikut:

a) Keputusan mengenai jenis kesulitan belajar anak (berat dan ringanya)

b) Keputusan mengenai faktor-faktor yang ikut menjadi sumber penyebab kesulitan belajar

c) Keputusan mengenai faktor utama penyebab kesulitan belajar dan sebagainya.

Dalam rangka diagnosis ini biasanya diperlukan berbagai bantuan tenaga ahli, misalnya:

1) Dokter, untuk mengetahui kesehatan anak.

2) Psikolog, untuk mengetahui tingkat IQ anak.

3) Psikiater, untuk mengetahui kejiwaan anak.

4) Sosial worker, untuk mengetahui kelainan sosial yang mungkin dialami anak.

5) Ortopedagogik, untuk mengetahui kelainan-kelainan yang ada pada anak.

6) Guru kelas, untuk mengetahui perkembangan belajar anak selama di sekolah.

7) Orang tua, untuk kebiasaan anak dirumahdan sebagainya, tergantung pada kebutuhan.

3. Prognosis

Prognosis artinya "ramalan". Apa yang telah ditetapkan pada tahap diagnosis, akan menjadi dasar utama dalam menyusun dan menetapkan ramalan mengenai bantuan apa yang harus diberikan kepadanya untuk membantu mengatasi masalahnya. Dalam hal ini berupa:

1) Bentuk treatmen yang harus diberikan.

2) Bahan/ atau materi yang diperlukan.

3) Metode yang akan digunakan.

4) Alat bantu belajar mengajar yang diperlukan.

5) Waktu (kapan kegiatan itu dilaksanakan)

Jadi, prognosis adalah merupakan aktivitas penyusunan rencana atau program yang diharapkan dapat membantu mengatasi masalah kesulitan belajar anak didik.

4. Treatment, (Perlakuan)

Perlakuan disini maksudnya adalah pemberian bantuan pada anak yang bersangkutan (yang mengalami kesulitan belajar) sesuai dengan program yang telah disusun pada tahap prognosis tersebut. Bentuk treatment yang mungkin dapat diberikan adalah melalui: bimbingan belajar kelompok, bimbingan belajar individu, pengajaran remedial, pemberian 


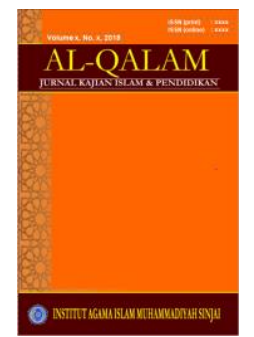

AL-QALAM

Jurnal Kajian Islam \& Pendidlikan

Volume 7, No. 1, 2015

ISSN (print) : 1858-4152

ISSN (online) : 2715-5684

Homepage : http://journal.al-qalam.iaims.ac.id

bimbingan pribadi untuk mengatasi masalah psikologis dan bimbingan orang tua, serta menagatsi kasus sampingan yang mungkin ada.

Adapun yang harus memberikan treatment, tergantung pada bidang garapan yang harus dilaksanakan. Kalau yang harus diatasi terlebih dahulu itu ternyata penyembuhan penyakit kanker yang diderita oleh anak, maka sudah barang tentu seorang dokterlah yang berwewenang menanganinya. Sebaliknya kalau bentuk treatmennya adalah memberikan pengajaran remedial dalam bidang studi matematika, maka guru matematikalah yang lebih tepat untuk melaksanakan treatment tersebut, dan seterusnya.

\section{Evaluasi}

Evaluasi juga disebut pengukuran yaitu sebagai pemberian angka kepada suatu atribut atau karakteristik tertentu yang dimiliki oleh orang. Hal atau obyek tertentu menurut aturan atau formulasi yang jelas. Keberhasilan pembelajaran diukur dengan berbagai cara, penampilan, rekaman, observasi, wawancara, dan lain sebagainya; sedangkan dalam pembelajaran konvensional keberhasilan pembelajaran biasanya hanya diukur dari tes. ${ }^{30}$

\section{Solusi Terhadap Masalah Belajar}

Pemecahan masalah (solusi) terhadap masalah kesulitan belajar hendaknya disesuaikan dengan jenis masalah yang dihadapi siswa atau peserta didik. Berarti ada dua sumber dua masalah kesulitan belajar, yaitu masalah yang berasal dari dalam diri anak didik (internal) dan masalah yang berasal dari luar anak didik (eksternal). Dengan solusi yang tepat sesuai dengan jenis kesulitan belajar anak didik akan diperoleh hasil belajar yang lebih baik.

Disisi lain, hal penting yang harus diingat bahwa kesulitan yang yang ditemui oleh anak didik harus memperoleh perhatian secara terus menerus baik dari orang tua murid maupun dari guru. Motivasi dari dalam diri anak didik harus ditanamkan kuat agar senantiasa bersemangat dalam meraih hal-hal yang baik dan konstruktif dengan cara belajar yang efektif. Langkah-langkah belajar efektif adalah mengetahui;

\section{Diri sendiri}

2. Kemampuan belajar anda

3. Proses yang berhasil anda gunakan, dan dibutuhkan

4. Minat, dan pengetahuan atas mata pelajaran anda inginkan. ${ }^{31}$

30 Wina Sanjaya, Strategi Pembelajaran Berorientasi Standar Proses Pendidikan, (Jakarta: Prenada Media Group, 2001), hlm. 261-262.

${ }^{31}$ Umi Basiroh, Pembelajaran, hlm.126-127. 


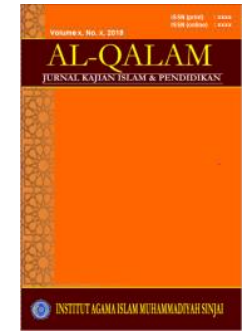

AL-QALAM

Jurnal Kajian Islam \& Pendidlikan

Volume 7, No. 1, 2015

ISSN (print) : 1858-4152

ISSN (online) : 2715-5684

Homepage : http://journal.al-qalam.iaims.ac.id

Sedangkan cara pengaturan waktu yang efektif untuk belajar adalah:

1. Beri waktu yang cukup untuk tidur makan dan kegiatan hiburan.

2. Prioritaskan tugas-tugas

3. Luangkan waktu untuk diskusi/ mengulang bahan sebelum masuk kelas.

4. Atur waktu untuk mengulang bahan pelajaran setelah kelas. Ingatlah bahwa kemungkinan terbesar untuk lupa terjadi dalam waktu 24 jam tanpa review.

5. Jadwalkan waktu 50 menit untuk setiap sesi belajar.

6. Pilih tempat yang nyaman (tidak mengganggu konsentrasi) untuk belajar.

7. Rencanakan juga "deadline"

8. Jadwalkan waktu belajarmu sebanyak mungkin pada pagi/ siang/ sore hari.

9. Jadwalkan reviw bahan pelajaran mingguan.

10. Hati-hati jangan sampai diperbudak oleh jadwalmu sendiri. ${ }^{32}$

\section{PENUTUP}

Dari uraian diatas dapat disimpulkan bahwa belajar adalah suatu proses dengan harapan untuk meraih suatu tujuan dan merupakan perubahan yang relatif permanen dalam prilaku atau potensi prilaku sebagai hasil dari pengalaman atau latihan yang diperkuat. Belajar merupakan akibat adanya interaksi angtara stimulus dan respon. Seseorang dianggap telah belajar sesuatu jika dia dapat menunjukkan perubahan prilakunya.

Faktor yang mempengaruhi seseorang dalam belajar itu banyak jenisnya. Faktor-faktor belajar itupun dibagi menjadi dua bagian yaitu faktor interen yang berasal dari dalam dan faktor eksteren yang berasal dari luar. Faktor internal banyak dipengaruhi dari dalam diri siswa itu sendiri dan faktor eksternal dipengaruhi oleh lingkungan luar. Jika pengaruh hambtan dalam belajar kecil maka proses pembelajaran akan lancer dan tujuan pendidikan yang diharapkan akan berhasil.

${ }^{32}$ Ibid. hlm. 127. 


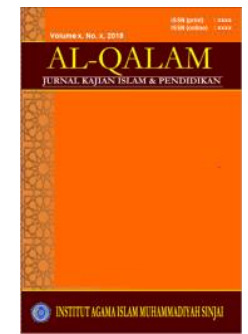

AL-QALAM

Jurnal Kajian Islam \& Pendidikan

Volume 7, No. 1, 2015

ISSN (print) : 1858-4152

ISSN (online) : 2715-5684

Homepage : http://journal.al-qalam.iaims.ac.id

\section{DAFTAR PUSTAKA}

Basiroh Umi, Pembelajaran PAI Strategi dan Metedologi, Yogyakarta: Idea Pres, 2012, Cet. Pertama.

Dalyono M., Psikologi Pendidikan, Jakarta: Rineka Cipta, 1997.

Dimyati dan Mudjiono, Belajar dan Pembelajaran, Jakarta: Rinaka Cipta, 1997.

Departemen Agama RI, Al-Qur'an dan Terjemahanya, CV Penerbit J-ART, Bandun, 2005

Hakim Thursan, Belajar secara Evektif, Jakarta: Puspa Swara, 2000.

Hamalik Oemar, Proses Belajar Mengajar, Jakarta: PT Bumi Aksara, Cet. VI, 2007.

http://www.anneahira.com/faktor-faktor-yang-mempengaruhi-prestasi-belajar-siswa.htm

Sardiman, Interaksi dan Motivasi Belajar Mengajar, Jakarta: PT. Raja Grafindo, 2005.

Sanjaya Wina, Strategi Pembelajaran Berorientasi Standar Proses Pendidikan, (Jakarta: Prenada Media Group, 2001).

Setyorini Tity, Strategi Pembelajaran Pendidikan Agama Islam di Sekolah, Teori, Metedologi dan Implementasi, Yogyakarta: Idea Press, Cet. Pertama, 2012.

Suharyanta, Strategi Pembelajaran Pendidikan Agama Islam di Sekolah, Teori, Metedologi dan Implementasi, Yogyakarta: Idea Press, Cet. Pertama, 2012.

Slameto, Belajar dan Faktor-Faktor Yang Mempengaruhinya, Jakarta: Rineka Cipta, 1991.

Soemanto Wasty, Psikologi Pendidikan, Jakarta: Reineka Cipta, 1990.

Tohirin, Psikologi Pembelajaran Pendidikan Agama Islam, Jakarta: Edisi Revisi , PT. Raja Grafindo Persada, 2006. 